\title{
CALVIN AS A CIVIC AND SOCIAL INFLUENCE.
}

BY PROF. GEORGE BOARDMAN EAGER, D.D., LL.D.

It would seem safe to say concerning those that caricature and curse as well as those that exalt and praise the immortal Genevan, as Dr. Minton says in the August North American Review, that a genuine first-hand knowledge of the personality of the great reformer, of the actual nature of his manysided work, of the real principles which he taught, or of his posthumous influence upon history, is by no means deemed by them an indispensable requisite for their work. It is probably true, too, that no leader of any great movement is regarded today with more general disfavor or with less real comprehension than Calvin.

The fact, however, that so large a part of Christendom has joined this year in celebrating the four hundredth anniversary of his birth is prima facie evidence that there is a sense in which he still lives and compels recognition. Even the International Congress of Religious Liberals, that endorsed the movement to erect the monument to Servetus at Vienne, gave its approval to the monument unveiled to Calvin at Geneva on July 15th,-- "to that illustrious man and the influences proceeding from him"! The festival, it would seem, indeed, was the whole world's, for the nations of the earth, through their representatives, united in according homage to the memory of this illustrious thinker, writer, reformer, man. Moreover, if this celebration and the interest it has aroused have stimulated many others, as they have the writer, to go behind the traditional Calvin by a restudy of his life and letters and "posthumous influence," with a view to "a first-hand knowledge of the great reformer," of "his many-sided work," and of "the influences proceeding from him," it will not have been in vain. There is a sense in which we of the twentieth century should with one accord welcome a renaissance of Calvinism. 
Certainly whatever else it has done, or left undone, this anniversary has served to bring out into the clear some things not so well known about Calvin; for instance, the beneficent extent of his influence along practical, civic and social lines. Incidentally, of course, it has helped to correct some radically wrong ideas, and among them these:-that Calvin and Calvinism stand exclusively for a theological, dogmatical and ecclesiastical movement; that Calvin himself was 'a grim, dour churchman who was never happier than when committing the souls of poor, frail, human beings to an eternity among the damned'; and that he was wholly or chiefly responsible for that solitary crimen nefandum which history with persistent and farreaching unfairness has cast into the teeth of the great reformer, the burning of Servetus.

But this well organized celebration has rendered no more valuable or timely service, I take it, than that by which it has brought the thinking world to recognize in an approximately adequate way that Calvin was not simply the great thinker and theologian of the sixteenth century, who did more than any other to organize the chaotic intellectual elements of the times; but that he was, beyond question, the supreme social force of the age as well, and did vastly more than any other to co-ordinate and direct and project into the future the far-reaching social forces of the Reformation; in short, that it was Calvin who, more than any other, under God, gave the model, formulated the ideas and exerted the influence which affected more or less profoundly and formatively, not only the organization of all the independent Protestant denominations, but the whole complex civilization of the Protestant world as well.

In order to a full appreciation of this fact we may well recall some things about the man, the times in which he lived, and the conditions and forces that gave form, direction and efficiency to his labors.

In the first place he was a Frenchman, and as such characteristically practical, not doctrinaire. $\mathrm{He}$ cared nothing for speculation for its own sake. Intimate knowledge of the French shows them careful even of little things, true to their motto, 
peu et peu, "little by little;" ascending, after all and always, not so much by bounds and leaps as step by step. Mercurial and effervescent on the surface, they have always been stable and conservative at bottom. So it was with Calvin. The French nation itself, though often impelled to a work of destruction, has been always in aim, and ultimately to some degree in achievement, constructive. To denounce even that tumultuous and seemingly godless period, known pre-eminently as "the Revolution," as one of revolution only, rather than of evolution, is to ignore the fact, now conceded by all historians, that the "hell-broth" had been long a-brewing, that it was by no means confined to France, that it was, indeed, racewide in its workings and bearings, having reference at bottom more to freedom of manhood, the emancipation of the thinker and the fuller development of the citizen, than to mere liberation from political thralldom. It is worth while, I say, to recall that Calvin was a Frenchman, a typical Frenchman, and a sort of epitome and exponent of the French temperament and character, its qualities and limitations.

Moreover, by birth he was an aristocrat, rather than a democrat. His father, Gerard Chauvin, though a cooper, was of noble family, and his mother likewise was high-born, and distinguished for her beauty and refinement, as well as for her piety. It is claimed that he inherited from his father his methodical habits, and the gravity of his disposition, tinctured with censoriousness, which led his schoolmates to fasten on him the nickname of "Accusative;" and from his mother his highly sensitive nervous organization and consequent irritability, his fine patrician features, his native courtesy of manner, and that constitutional shyness which to the end of his life, as contradictory to fact as it may seem to some, he never wholly overcame. His father, we are told, did not err on the side of over-indulgence. He kept his children in great awe, exacting obedience like an Oriental patriarch, testifying his love more by restraining their youthful propensities than by any over-fond caresses or indulgences. The future reformer, though, looked back on his severe training with unfeigned gratitude: "I had," 
he says, "a somewhat severe father, but I rejoice at it, as the source of any virtues I may possess." Born of such perents and trained in such a home, it is not strange that Calvin gave early evidence of deep religious bias and feeling. His boyhood, too, we may readily believe, was not only free from vice, but was that of an incipient reformer; he was known even then to sharply reprove his companions who were loose in their morals. He was, by no means, an ordinary, bouyant, frolicsome youth, but singularly precocious and prematurely grave and restrained. Further, as to his training, Calvin tells us that, when a boy, he was received into the house of the illustrious family of Genlis de Hangert, which held for two generations the episcopal see at Noyon, and that he was at school there with one of the sons of this family. Later he pursued his studies in company with the children of the noble house of Mommor, but at his father's expense. This intimacy with great families fruited in rich results for him, as imparting to him that air of good breeding which never forsook him, and as securing for him a social refinement and a liberal culture which shone forth with rare lustre to the last.

As to the times and conditions under which Calvin lived, we do well to recall that what is styled the intolerance of Calvin, culminating logically, as it is supposed, in the burning of Servetus, was not original with Calvin, nor was it the expression of a special characteristic of Calvinism; but, on the contrary, it was an inheritance from the past, a fatal after-effect of a system, grey with age, which Calvin found in full sway, under which he grew up, and from which, in the very nature of things, it was impossible for him and for the system which acquired his name at once and entirely to liberate themselves. It dates back from Constantine the Great. It was originally a reaction against the horrible persecutions which the first Christian Emperor's Pagan predecessors on the throne had inflicted upon the sect of the Nazarene. It accepted as a datum from a still remoter past, that it was the duty of civil government to extirpate every form of false religion and belief. So it was no find or fiat of Calvinism. It had been held and defended by all Roman Catholic theologians, as it had been re- 
lentlessly applied by all reigning Christian princes. In the time of Luther and Calvin the conviction was universal that it was true in principle and right in practice. As Kuyker shows, every famous theologian of the period, Catholic and Protestant, Melancthon first of all, approved of the death by fire of the notorious heretic, Servetus; and the scaffold erected by the Lutherans at Leipzig for Krell, the thorough-going Calvinist, was infinitely more reprehensible, when looked at from a Protestant standpoint. According to the reigning idea of the times, among Catholies and Protestants, there was but one Church of Christ on earth, and it was the function and duty of the Magistrate to protect that Church from schisms, heresies and sectaries, if need be by death. Let us make our appeal to clear historical facts, and let us try to be fair in judging this matter. Let us understand, too, that the underlying and essential characteristics of Calvinism should be sought, not in what it has adopted unmodified from the past, so much as in what it has newly created, or, after subjecting to the test of its own fiery, Scriptural crucible, placed its stamp upon. After the lapse of three and a half centuries one thing is certain, the "free churches" have flourished exclusively in those countries which were touched and kindled by the breath of Calvinism, viz., those in Switzerland, the Netherlands, England, Scotland, and the United States of North America.

Let us recall one other fact, which many forget, if they ever knew, that, so fas as history shows, Calvin, unlike Luther and Zwingli, was never formally ordained, either as Roman Catholic priest, or as Protestant minister of the Gospel. Nevertheless he was theologian, teacher and preacher. This startles us at first blush, but in those times of the universal union of church and state, and of the secularization of sacred things, it was by no means uncommon. After his conversion to the Reformed faith and careful re-study of the Greek New Testament, Calvin heartily espoused the doctrine of the universal priesthood of believers, and, directly or indirectly, sent out many a "laypreacher" to propagate the new doctrine of salvation. But, judged by history, he was a statesman and social reformer, no 
less than a churchman. His father, though originally designing him for the priesthood and starting him in his education accordingly, later dissuaded him from taking orders and had him prepare himself for the more lucrative vocation of the law, which he did under the two most famous jurists and rival leaders of their time, Petrus Stella and Andrea Alciate. $\mathrm{He}$ received the degree of Bachelor of Laws at Orleans in 1531; and on leaving the University later was unanimously offered the degree of Doctor of Laws without fee, in recognition of his rare legal attainments and his success in teaching on one occasion in the absence of the professor. His legal studies and his large knowledge of human nature, beyond question, were of vast benefit to him in his multiform work of organization and administration in Geneva.

Calvin's coming to Geneva and "call" to service there, it is worth while to notice, were on this wise. A fierce struggle was on in the little republic, precipitated by the preaching of the Reformed faith by William Farel, first in 1532. A disputation, after the fashion of the times, had been held before "the council." The Romanists had been worsted, a church had been conceded to the Protestants, and a general assembly of the people, 1536, had sworn to God that by his help they would live according to the holy evangelical religion and Word of God lately preached to them, renouncing the mass, images and every other papal abuse. Thus things stood on the memorable evening when Calvin entered the gates of Geneva. $\mathrm{He}$ had come "only for a single night," and so would keep his presence secret. But Farel found him out, hurried to the inn and with fiery zeal urged him to stay and help. Calvin, shrinking with his whole soul, made every excuse he could:- he was a student, he did not wish to bind himself to one church, but would try to serve all, he was naturally timid and loved retirement, etc. But Farel was not to be daunted. With the burning zeal of an old prophet he arose, placed himself dramatically before the young man, and in the most solemn manner pronounced a curse on his "studies," if they were to be allowed to keep him from coming to the help of the Lord, to the help of the Lord against 
the mighty. "I declare unto thee on the part of God," he thundered, "that, if thou refuse to labor with us here in God's work, he will curse thee; for, in pleading thy 'studies' as an excuse for leaving us, thou seekest thyself more than God!" It was enough. Calvin testifies that it filled him with awe and he felt powerless to resist. Ever sensitive to the voice of Duty, he laid aside his preferences and immediately obeyed what he conceived to be the behest of God through his servant and messenger. "By this imprecation," to quote his own words, "I was so stricken with terror that I desisted from the journey which I had undertaken." He settled down to a work which it is not easy now to define. It was at the instance of Farel, but on the appointment of the council. It was first to deliver a course of lectures in St. Peter's Cathedral, without fixed salary, as the record of February 13, 1537, shows ("Six gold crowns are given to Calvin, seeing that he has hitherto scarcely received anything"). How unknown the frail young foreigner was, and how slight was the impression he first made, is indicated by the minute of September 5, 1536. "Master William Farel stated the need for the lectures begun by this Frenchman at St. Peters." He is not even so much as named.

Nevertheless this little Swiss city, and this Republic of Geneva, were destined to become world famous and influential chiefly through "this Frenchman." The city was to become known to the world, indeed, as "the City of Calvin," and the Republic was to owe to him at last the most important role that it should play in history.

Soon after Calvin began to preach he was admitted as one of the stated pastors of Geneva. At first the people were but slightly impressed by him as man or minister. About three months after his coming the two Reformers, Farel and Calvin, scored their first real success in the reformation of the Genevan church. A Confession of Faith prepared chiefly by Calvin was laid by Farel, the chief pastor, before the council and adopted by that body. The articles emphasized the close connection between faith and conduct. Marriages were to be celebrated only in public, after proclaiming the banns three times. All 
shops should be shut on Sundays during the services; all images remaining in the churches should be removed. Calvin also proposed and virtually established a system of compulsory education, and prepared and introduced his famous catechism for children-compact, practical, and breathing the spirit of derotion. Laws were already in foree forbidding vice and requiring attendance on public worship. The magistrates now warmly supported the reformer's efforts to enforce these regulations. Calvin showed up, indeed, not as the timid scholar, anxious to be left alone with his books, but as the born ruler of men, with a genius for organization and leadership. His principles and severity involved him in numberless conflicts with "the Libertines," in which for a time defeat and victory seemed suspended in an uncertain balance; but he triumphed at last and made Geneva the wonder of the world for civil order, pure morals, liberal learning, also a home and nursery of arts and industries. The external motive that led Calvin to write his "Institutes" was to defend his Reformed brethren and their doctrines against the misrepresentations and persecutions of the King of France, who charged that they were the enemies of civil order, that what he sought to punish them for was, not their religious opinions, but their social and political doctrines. Calvin's work at Geneva, no less than his "Institutes," was a defence of the Reformers against all such charges. We must take account of his spirit and work at Geneva as reformer and statesman, no less than his formulated doctrines, if we would account for his stupendous influence on posterity. He found Geneva a veritable Sodom, it has been said, but he left it a model of good morals and civil order.

It was a time when all Europe was waking up politically and socially, as well as religiously and intellectually; and "this Frenchman" had here the unique opportunity, under God, to head the procession and guide the most aggressive wing of the multiform movement on the way toward its goal; and he was fitted to do it ! He had had the training of a priest, of a classieist, of a gentleman, of a jurist-and all combined with his enormous powers, early matured, to turn out the finished 
product. The result is such that after three and a half centuries of his leadership and "posthumous influence," an exPrime Minister of Holland can say: "Historically, Calvinism indicates the channel in which the Reformation moved, in so far as it was not Lutheran, Anabaptist, or Socinian. Philosophically, it stands for that system of conceptions which, under the influence of the master-mind of Calvin, raised itself to dominance in the several spheres of modern life. As a political name it indicates that political movement which has guaranteed the liberty of nations in constitutional statesmanship." Let us hear some other testimonies. Buckle, not a friend of Calvin, concedes that "the doctrines which in England are called Calvinistic have always been connected with a democratic spirit," and cites the republics of Switzerland, Holland and North America as cases in point. Calvinism, he says, created the Dutch Republic, and made it "the first free nation to put a girdle of empire around the world." Motley says: "It would certainly be unjust and futile to detract from the vast debt which that republic (the Netherlands) owed to the Genevan church." He would have us believe, too, that the seed thoughts of Calvinism, sown in the blood-stained soil of France, gave rise at last to a permanent republic there. They were fighting there, he says, the same great battle as were the Netherlanders. "The valiant cavaliers of Dauphiny and Provence knelt on the ground before the battle, smote their iron breasts with their mailed hands, uttered a Calvinistic prayer, sang a psalm of Marot, and then charged upon Guise under the white plume of the Bearnese." And it was on the Calvinistic weavers and clothiers of Rochelle, according to him, that the Great Prince relied in the hour of danger. He concludes his general survey with these significant words: "Thus to the Calvinists more than to any other class of men, the political liberties of Holland, England and America are due." It was the illustrious Calvinist prince, William of Orange, who at the crisis saved English liberty-he who, as Macauley says, "found in the strong and sharp logic of the Genevan something suited to his intellect and his temper." Of his victory the historian says: 
"It has been of all revolutions the most beneficent. It was England's best." Even David Hume declares: "The precious spark of liberty was kindled and preserved by the Puritans alone. It was to this sect that the English owe the whole freedom of their constitution." Taine says, unequivocally and sweepingly: "They founded England; they founded Scotland; they founded the United States; and at this day they are by their descendants founding Australia and colonizing the world." Ranke gives it as his judgment, and Froude, Bancroft and others agree with him: "John Calvin was virtually the founder of America." Surely, in view of such testimonies the sons and daughters of the followers of Calvin today need not fall into shamed silence or purse up their lips in disdain, when the name of this Frenchman is mentioned. The ideas and spirit of Calvin and the Calvinistic Reformation, taken in the broadest sense, have ultimately worked for good the world over, even in priest-ridden Italy and autocratic Russia, in the crumbling and reconstruction of the Turkish Empire, in Persia, and Korea, in the Flowery Kingdom and the hoary Sunrise Empire; and the end is not yet. The fashion and trend of thinking in our day make it especially noteworthy that Calvin so long ago clearly perceived, much more clearly than many of his followers, that the outcome of the Gospel was social righteousness. He was far from content with the salvation of the individual, or with the mere getting of men one by one "out of Hell and into Heaven." Beecher is eloquent, but hardly fair to this fact, when he says: "The Calvinist sees man pressed, burdened, urged on, by the most mighty influencing forces. He is on the march for eternity, and is soon to stand crowned in heaven or to lie sweltering in hell, there to continue forever and ever. Who shall dare to fetter such a being? Get out of his way! Hinder him not, or do it at the peril of your own soull Ler him work out his own salvation as he can!" Calvin was most deeply concerned about the bearing of truth upon conduct and character, of the individual and society, here and now. He sought in very truth to establish the Kingdom of God upon earth. That attitude of Government known as "laissez faire," 
coveted and called for later by the people, was unknown to him. He did not believe that all that men need of government is that it give them room to help themselves. His was the truer social spirit, struggling to utter itself even then in a choking atmosphere, and to shake itself free of the binding chains of custom; a spirit finding its freest and fullest expression only in our own day. It is speaking all about us today, no longer content to say to Government, "Hands Off l" It appeals and pleads: "Help the struggling and suffering! Help the miner to get a sight of the sun; open the door of the factories and release the little children; let the toilers, old and young, breathe the fresh air; train the young citizen for the duties of citizenship; build fit and adequate asylums for the insane and defective; and consider and care for the helpless poor." So in essence spake the spirit of Calvin in Geneva, and so more and more speaks the true spirit of Calvinism today. Its voice is heard above the din of controversy. It is demanding as never before the cleansing of our cities and villages, and the shaping of our legislation, municipal, state and national, so as to make it easier to do right and harder to do wrong. As Dr. John Clifford says, viewing it as the new and nobler spirit of our times: "It is marching through the world. It has appeared even in Turkey. The 'new school' in Constantinople has for the pivot of its teaching 'civic instruction'-the training of the rising generation in a knowledge of its duties and of its social and political rights and of the obligations of brotherhood." It has invaded even conservative Oxford. "There is a wave of social enthusiasm sweeping through the Oxford colleges," says Dr. Estlin Carpenter. This widespread interest in social and political matters may well fill us with hope. "The fact is," says Dr. Carpenter, "if the church does not learn to control the world, the world will certainly absorb the church." Christians of all names may safely welcome this spirit, if not Calvin's outgrown method, and give it free course to be glorified in determining their choices, motives, methods, arguments and appeals. For, as we are beginning to see at last, it is inspired of God. It is the very spirit of the Lord Jesus, the Spirit of "his cross that leads 
the generations on," the spirit of a self-sacrificing and selfpurifyingly altruism that leaves no room for the wasteful and destructive work of a self-centered egoism. "We call it the zeit-geist," says Dr. Clifford, "the spirit of the age.' And so it is; but it is just as truly the spirit of Him who came not to be ministered unto, but to minister, and to give his life a ransom for many." And surely this great Calvinistic movement, that has been one manifestation of it, in spite of its many errors, defects and excesses, is of God, and is helping to bring in "that sreat, far-off, divine event toward which the whole creation moves." 